\title{
Pengembangan Bisnis UMKM Kopi Lelet Melalui Peningkatan Kapabilitas Manajerial dan Kapasitas Produksi di Kabupaten Rembang
}

\author{
Hersugondo ${ }^{1)^{*}}$, Ahyar Yuniawan ${ }^{2)}$, dan Idris ${ }^{3)}$ \\ 1), 2), 3) Fakultas Ekonomika dan Bisnis, Universitas Diponegoro Semarang \\ *email: hersugondo@lecturer.undip.ac.id
}

\begin{abstract}
Abstrak - Kopi merupakan salah satu minuman yang sangat digemari oleh masyarakat di dunia. Kopi yang diproduksi dan dikonsumsi oleh masyarakat Rembang disebut Kopi Lelet. Kopi lelet adalah kopi khas Rembang. Kopi lelet identik dengan kegiatan nglelet dengan media batang rokok dan tintanya menggunakan lethekan (ampas) kopi lelet. UMKM yang memproduksi kopi lelet diantaranya adalah Kopi Lelet Cap Cangkir dan Cap Leo. Namun demikian, kedua UMKM tersebut memiliki kendala dalam mengembangkan bisnisnya, yaitu: 1) Terbatasnya wawasan dan pengetahuan tentang manajemen dan kewirausahaan yang dimiliki oleh UMKM Kopi Lelet; 2) Proses produksi masih manual, belum menggunakan mesin sehingga hasil produksi masih terbatas; 3) Daerah pemasaran masih terbatas di Kabupaten Rembang dan konvensional dengan kemasan yang masih sederhana; 4) Pengelolaan keuangan belum baik, pendapatan masih digunakan untuk kebutuhan sehari-hari; dan 5) Terbatasnya permodalan yang dimiliki oleh UMKM Kopi Lelet mitra, khususnya untuk pengadaan peralatan produksi. Untuk mengatasi permasalahan tersebut, maka tim melakukan kegiatan: 1) Mengadakan pelatihan kewirausahaan dan manajemen usaha; 2) Memfasilitasi penggadaan mesin penggiling kopi dan pengepres kemasan; 3) Memfasilitasi penggadaan kemasan produk dengan desain yang menarik; dan 4) Pedampingan usaha UMKM Mitra Kopi Lelet khususnya pencatatan transaksi usaha. Hasil dari kegiatan pengabdian ini adalah: 1) UMKM Mitra Kopi Lelet bisa mengimplementasikan manajemen usaha yang baik; 2) Tersedianya mesin penggiling kopi dan pengepres kemasan; 3) Tersedianya kemasan produk yang menarik; dan 4) UMKM Mitra Kopi Lelet sudah memiliki pembukuan yang sederhana.
\end{abstract}

Kata kunci: Pengembangan Bisnis, Kapabilitas Manajerial, Kapasitas Produksi, UMKM Kopi Lelet

\section{Business Development Of Lelet Coffee Smes Through Improving Managerial Capability And Production Capacity In Rembang Regency}

\begin{abstract}
Coffee is one drink that is very popular with people in the world. Coffee produced and consumed by the Rembang public is called Kopi Lelet. Lelet coffee is typical Rembang coffee. Lelet coffee is identical to the activity of nglelet with the media of cigarettes and the ink uses lethekan (pulp) lelet coffee. SMEs that produce lelet coffee is Cap Cangkir and Cap Leo Lelet coffee. However, both SMEs have obstacles in developing their business, namely: 1) Limited insight and knowledge about management and entrepreneurship owned by Kopi Lelet SMEs; 2) The production process is still manual, not using a machine so the production results are still limited;3) Marketing areas are still limited in Rembang Regency and conventional with still simple packaging; 4) Financial management is not good, income is still used for daily needs; and 5) Limited capital owned by partner coffee lelet SMEs, especially for the procurement of production equipment. To overcome these problems, the team undertook the following activities: 1) Conducting entrepreneurship training and business management; 2) Facilitating the procurement of coffee grinding machines and packaging presses; 3) Facilitating the procurement of product packaging with attractive designs; and 4) Business assistance for Kopi Lelet SMEs partner especially recording business transactions. The results of these community service activities are: 1) Lelet coffee partners SMEs can implement good business management; 2) Availability of coffee grinders and packaging presses; 3) Availability of attractive product packaging; and 4) Lelet coffee partner SMEs already has a simple bookkeeping.
\end{abstract}

Keywords: Business Development, Managerial Capability, Production Capacity, Lelet Coffee SMEs 


\section{PENDAHULUAN}

Kopi merupakan salah satu minuman yang sangat digemari oleh masyarakat di dunia. Kopi merupakan minuman yang sangan populer sejak berabad-abad yang lalu. Sejarah mencatat bahwa penemuan kopi sebagai minuman berkhasiat dan berenergi pertama kali ditemukan oleh bangsa Etiopia di Benua Afrika sekitar 3000 tahun (1000 SM) yang lalu (Ekawati, 2016). Pada abad ke-10, seorang ilmuwan dari Bukhara yang bernama Ibnu Sina (Avicenna) seorang dokter sekaligus seorang filsuf melakukan penelitian tentang kopi dan menemukan suatu kandungan yang terdapat dalam kopi yang disebut bunchum atau saat ini disebut dengan kafein. Sejak saat itu sampai saat ini penelitian tentang kopi terus dilakukan berkaitan dengan kandungan yang ada di dalam kopi dan manfaatnya (Gardjito dan Rahadian, 2011). Kopi merupakan minuman yang tidak mengandung alkohol. Selain sebagai obat dalam budya pengobatan tradisional di Arab, China dan India juga sebagai komoditas yang sangat diminati untuk diperdagangkan (Panggabean, 2011).

Kopi mengadung antioksidan, antioksidan pada kopi mampu mencegah kerusahkan selsel otak serta baik untuk kesehatan hati. Selain itu, bagi sebagian orang dengan rutinitas yang mengharuskan untuk beraktivitas di malam hari, kopi bisa menjadi alternatif minuman yang baik karena kandungannya tersebut. Beberapa hasil penelitian tentang kopi menyebutkan bahwa: Pertama, penelitian yang dilakukan oleh University of California, Los Angeles (UCLA) menemukan bahwa minum kopi dapat meningkatkan kadar plasma dari protein sex hormonebinding globulin (SHBG). SHBG adalah suatu hormon yang mengontrol aktivitas biologis hormone seks tubuh (testosteron dan estrogen) yang berperan dalam penyakit diabetes mellitus tipe 2. Kedua, para peneliti di Universitas McGill Amerika Serikat yang diterbitkan di jurnal Neurology menemukan bahwa asupan kopi dan kafein yang lebih tinggi punya hubungan dengan penyakit Parkinson yang lebih rendah. Ketiga, peneliti dari Milan Istituto di Ricerche Farmacologiche Mario Negri, Italia menemukan bahwa konsumsi kopi menurunkan resiko kanker hati sekitar 40\%, selain itu beberapa penelitian lain juga menunjukkan bahwa mengkonsumsi kopi tiga cangkir sehari risiko berkurang lebih dari 50\%.

Keempat, penelitian yang dilakukan oleh Kaisar Permanente Medical Care Program, California Amerika Serikat menemukan bahwa minum kopi dapat dapat menurunkan kematian yang disebabkan oleh sirosis hati. Kelima, penelitian yang dilakkukan oleh Beeth Israel Dacness Medical Cener (BIDMC) dan Harvard Scholl of Public Health menyimpulkan bahwa minum kopi dalam jumlah sedang melindungi seseorang terhadap gagal jantung, orang yang minum empat cangkir setiap hari memiliki risiko $11 \%$ lebih rendah untuk kejadian gagal jantung. Keenam, pengaruh minum kopi terhadap stroke memang masih kontroversial, kafein disebutkan dapat meningkatan tekanan darah sebagai salah satu faktor risiko stroke. Namun sebuah studi meta analisis di Korea pada tahun 2012 menyatakan minum kopi dapat mengurangi stroke. Begitu juga hasil penelitian dari Universitas Harvard bahwa konsumsi kopi secara sedang (3-4 cangkir sehari) memang ada hubungannya dengan penurunan risiko stroke, tetapi pada mereka yang jarang minum kopi, kejadian stroke justru bisa terjadi setelah mereka minum kopi (Ekawati, 2016).

Salah satu daerah yang memproduksi kopi secara tradisional adalah Kabupaten Rembang. Kopi yang diproduksi dan dikonsumsi oleh masyarakat Rembang disebut Kopi Lelet. Kopi lelet adalah kopi khas Rembang. Kopi lelet identik dengan kegiatan nglelet dengan media batang rokok dan tintanya menggunakan lethekan (ampas) kopi lelet. Jika dilihat sekilas, mungkin tidak ada perbedan dengan kopi jenis lain, tetapi kopi lelet memiliki kekentalan 
adonan kopi, cita rasanya yang kuat, lembutnya buliran pada kopi lelet dan cara menikmatinya. Lembutnya buliran kopi lelet lebih halus dibanding bulran kopi produksi pabrik, karena kopi lelet diproduksi oleh pedagang sendiri atau usaha mikro kecil dan menengah (UMKM) dengan beberapa kali proses penyaringan.

Cara penyajian kopi lelet juga berbeda dengan cara penyajian pada minuman kopi pada umumnya. Pertama, kopi dan gula dimasukkan dalam panci lalu dituangkan air panas ke dalamnya. Adonan ini masih harus kembali dimasak setelah benar-benar mendidih baru kopi disajikan. Sebagian besar para penikmat kopi lelet adalah para perokok, karena setelah mereka menikmati kopi sampai hanya tinggal ampasnya, ampas kopi dioleskan (dileletkan) pada batang rokok yang akan dihisabnya. Cara pengolesan (meleletkan) ampas kopi pada batang rokok juga menghasilkan karya seni yang unik sesuai dengan selera dan cara mengoleskannya. Setelah agak kering ampas kopi yang menempel pada rokok, maka rokok pun sudh siap untuk dinikmati.

Budaya nglelet di Kabupaten Rembang sampai sekarang belum ada yang tahu dengan pasti. Namun, mungkin ini juga ada hubungannya dengan budaya membatik yaitu batik tulis Lasem. Membatik dan nglelet sama-sama mengekspresikan motif-motif melalui suatu media dengan menggunakan tinta yang khas. Jika pada membatik menggunakan media kain dengan canting dan lilin serta warna-warna merah, sedangkan pada nglelet menggunakan media batang rokok dengan lethekan (ampas) kopi. Sehingga dapat dikatakan bahwa nglelet juga merupakan budaya yang turun temurun.

UMKM yang memproduksi kopi lelet di Kabupaten Rembang diantaranya adalah Kopi Lelet Cap Cangkir di Desa Sumberjo Kecamatan Rembang dan Kopi Leo di Desa Pragu Kecamatan Sulang Kabupaten Rembang. Di kecamatan Rembang sendiri menurut data dari Disperindagkop dan UMKM Kabupaten Rembang terdapat 50an warung kopi dan banyak warung-warung yang menjual kopi lelet. Sebagian besar masyarakat di Rembang senang mengkonsumsi kopi lelet di warung-warung sambil kongkow-kongkow dan juga ada yang mengkonsumsi di rumah.

Jumlah konsumen kopi dari waktu ke waktu selalu bertambah. Menurut Asosiasi Eksportir dan Industri Kopi Indonesia (AEKI) bahwa konsumsi kopi di Indonesia tumbuh $5 \%-6 \%$ per tahun dengan total konsumsi sekitar 4,5-5 juta kantong per tahun. Pertumbuhan konsumsi kopi di Indonesia saat ini di atas pertumbuhan produksi kopi yang berkisar antara $1 \%-2 \%$ per tahun. Permintaan kopi untuk kebutuhan pasar hotel dan restoran juga tumbuh sangat pesat (http://industri.bisnis.com/read/ 20160114/99/509504 diakses pada 30 Januari 2016). Selain itu produksi kopi di Indonesia per tahunnya lebih dari 400.000 ton (AEKI, 2016; Ekawati, 2016).

Dengan melihat potensi konsumen kopi yang mengalami tren kenaikkan dari waktu ke waktu serta adanya faktor budaya nglelet, maka sudah seharusnya usaha bubuk kopi lelet mendapat prioritas sehingga mampu berkembang sebagai salah satu sektor yang akan meningkatkan pendapatan masyarakat. Namun demikian, terdapat permasalahan yang dihadapi oleh UMKM kopi lelet UD Cangkir dan Kopi Leo, yaitu: 1) terbatasnya wawasan dan pengetahuan tentang manajemen dan kewirausahaan yang dimiliki oleh UMKM Kopi Lelet sebagai dasar untuk melakukan pengembangan usaha yang lebih baik; 2) Proses produksi masih manual, belum menggunakan mesin sehingga hasil produksi masih terbatas; Kemasan kopi lelet masih sederhana; 4) Pemasaran masih terbatas di Kabupaten Rembang dan konvensional; 5) Pengelolaan keuangan belum baik, pendapatan masih digunakan untuk 
kebutuhan sehari-hari; dan 6) Terbatasnya permodalan yang dimiliki oleh UMKM kopi lelet, khususnya untuk pengadaan peralatan seperti: mesin penggiling kopi dan pengepres kemasan plastik (sealer) yang bagus.

\section{METODE}

\section{Metode Pendekatan}

Pengabdian kepada masyarakat ini dilakukan pada bulan April sampai November 2019 di UMKM Kopi Lelet Cap Cangkir dan Cap Leo Kabupaten Rembang. Berdasarkan permasalahan yang dihadapi oleh mitra UMKM Kopi Lelet Cap Cangkir dan Kopi Lelet Cap Leo Kabupaten Rembang, maka metode pendekatan yang dilakukan oleh tim adalah:

1. Memberi penyuluhan kepada UMKM Kopi Lelet UD Cangkir dan Kopi Lelet Leo tentang pentingnya kemampuan manajerial dalam mengelola usaha, profesionalitas serta quality control.

2. Melakukan pelatihan manajemen dan kewirausahaan, yang mencakup: motivasi berwirausaha, manajemen produksi (quality control) inovasi dan kreativitas, pengelolaan keuangan dan manajemen pemasaran. Dengan pelatihan manajemen dan kewirausahaan ini diharapkan UMKM mitra dapat meningkat kemampun manajerialnya dalam mengelola usaha sehingga UMKM mitra dapat semakin berkembang dan mandiri.

3. Memfasilitasi penggadaan peralatan penggiling kopi dan pengepresan kemasan agar kualitas dan kuantitas produk semakin meningkat dan berdampak pada kenaikkan omzet UMKM mitra. Selain itu tim juga memfasilitasi media pemasaran dengan kemasan yang bagus dan menarik agar produk kopi lelet dari Kopi Lelet UD Cangkir dan Kopi Lelet Leo bisa lebih dikenal oleh masyarakat secara luas.

4. Melakukan pendampingan usaha berupa ide kreatif dan inovatif ke dalam produk yang dihasilkan mitra, sehingga produksi bisa efisien dan produktif. Tim pengabdian berperan sebagai pendamping/fasilitator yang memberikan arahan dan bimbingan secara teknis untuk menciptakan produk-produk kreatif. Luaran yang diharapkan berupa desain antara lain layout produksi yang efisien produktif dan kemasan yang menarik. Pada kegiatan ini mitra akan diberikan pelatihan bagaimana cara melakukan perencanaan, eksekusi dan pengendalian bisnis. Selain itu, pada kegiatan pendampingan ini tim juga akan melakukan pendampingan pencatatan transaksi keuangan yang diharapkan UMKM mitra memiliki pembukuan yang baik.

5. Mengajak dan mendorong Pemerintah Kabupaten Rembang, dalam hal ini Dinas Perindustrian, Perdagangan, Koperasi, dan UMKM (Disperindagkop dan UMKM) untuk lebih memperhatikan UMKM Kopi Lelet terutama Kopi Lelet UD Cangkir dan Kopi Lelet Cap Leo.

Dari proses identifikasi masalah, solusi sampai hasil yang diharapkan dapat dilihat pada

Gambar 1. di bawah ini. 


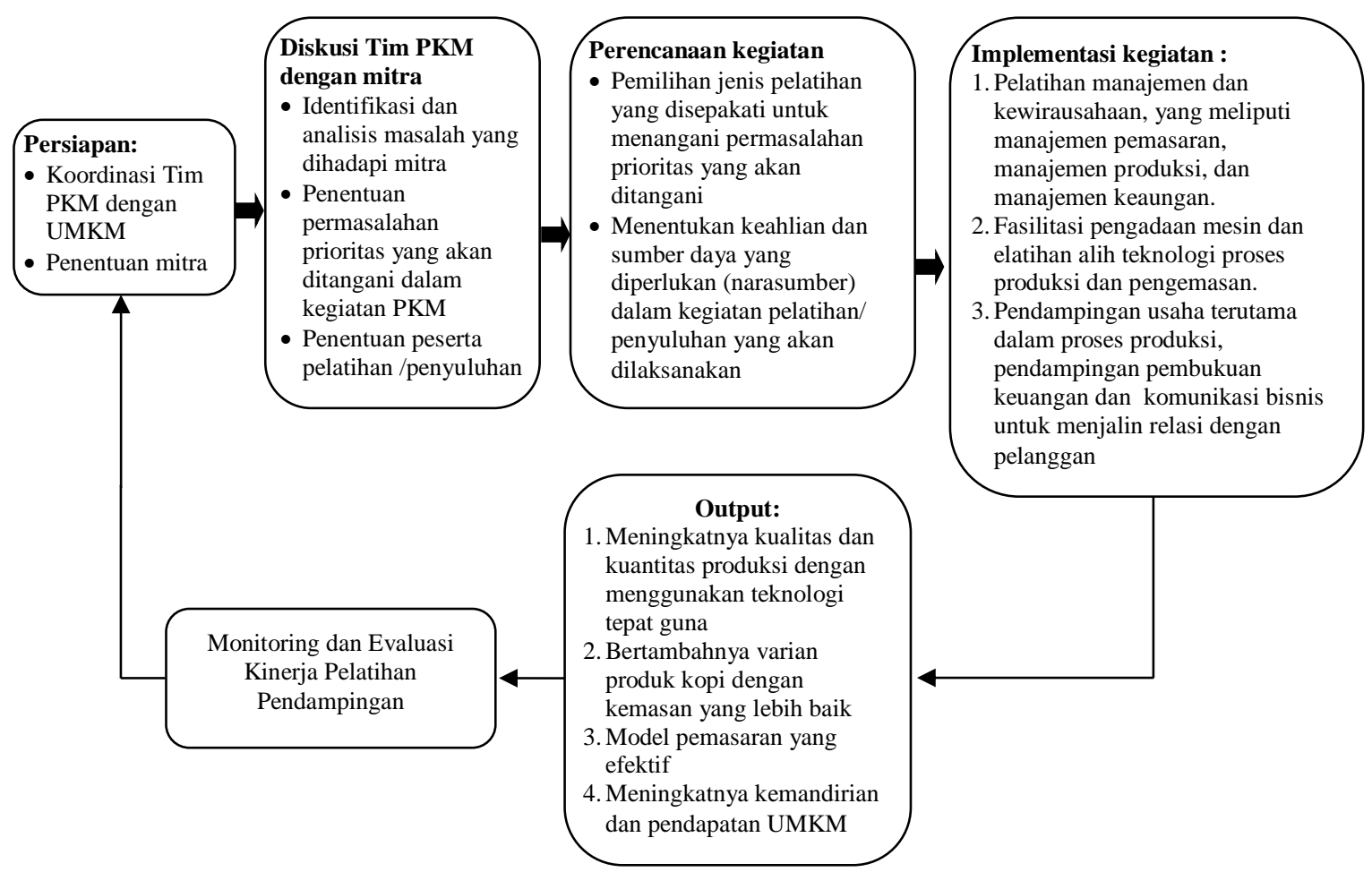

Gambar 1. Diagram Alir Proses Penyelesaian Masalah Mitra

\section{Pelaksanaan Kegiatan}

Tahapan pelaksanaan kegiatan pada pengabdian kepada masayarakat di UMKM Kopi Lelet Cap Cangkir dan Cap Leo di Kabupaten Rembang dengan penjelasan sebagai berikut:

1. Persiapan

Tahap awal dalam pelaksanaan program PKM, tim akan melakukan survei pendahuluan ke daerah mitra. Survei dilakukan untuk mengetahui permasalahan mitra dan solusi bersama yang nanti akan dilaksanakan.

2. Pelaksanaan

Setelah disepakati permasalahan dan solusinya, maka dilakukan peyuluhan tentang pentingnya kemampuan manajerial dalam mengelola usaha, profesionalitas serta quality control; kemudian melakukan pelatihan manajemen dan kewirausahaan, yang mencakup: motivasi berwirausaha, manajemen produksi (quality control) inovasi dan kreativitas, pengelolaan keuangan dan manajemen pemasaran; selanjutnya memfasilitasi pengadaan peralatan penggilingan dan pengepresan kemasan kopi serta pembuatan media pemasaran berupa kemasan agar produk kopi lelet dari UMKM Kopi Lelet mitra bisa lebih dikenal oleh masyarakat luas, serta menertibkan transaksi usaha dalam pembukuan keuangan yang sederhana.

3. Evaluasi

Kegiatan evaluasi perlu dilakukan agar pelaksanaan program PKM ini bisa diketahui tingkat ketercapaiannya dan manfaat yang diperoleh UMKM Kopi Lelet sebagai mitra. Rencana evaluasi pelaksanaan progarm PKM dilakukan dengan cara mengobservasi langsung di lapangan terhadap peserta pelatihan. Evaluasi pada program pelaksanaan 
PKM dengan melihat keberadaan usaha (mengecek ada tidaknya usaha, kejelasan kepemilikan usaha) kondisi usaha yaitu keadaan usaha sudah beroperasi atau belum beroperasi, prestasi yang dicapai terkait dengan omset, aset, penyerapan tenaga kerja, kondisi keuangan, jangkauan pasar, dan jumlah variasi produk.

\section{HASIL DAN PEMBAHASAN}

Pada tahap awal pelaksanaan kegiatan PKM pada Kopi Lelet Cap Cangkir dan Kopi Lelet Cap Leo, tim telah melakukan koordinasi untuk menggali lebih lanjut kebutuhan yang mendesak untuk difasilitasi oleh tim sebagaimana yang telah disepakati bersama waktu survei awal. Selain itu, tim juga memberikan masukan kepada UMKM Kopi Lelet atas permasalahan yang dihadapi, terutama tentang kemasan produk dan diversifikasi produk. Koordinasi yang dilakukan tim dengan UMKM Kopi Lelet Cap Cangkir dan Cap Leo berjalan dengan lancar dan bersifat kekeluargaan. Survei lanjutan dan koordinasi tim dengan UMKM mitra dimaksudkan untuk mencari solusi permasalahan UMKM mitra yang segera difasilitasi. Pada saat survei lanjutan dan koordinasi sebagaimana dapat dilihat pada Gambar 2 di bawah, tim menemukan mesin penggiling kopi yang sudah tidak layak digunakan lagi, informasi yang diperoleh dari UMKM mitra sering rusak dan bila dilihat tangki solar sudah terpisah dengan mesinnya, hal tersebut bisa berbahaya bagi pekerja.
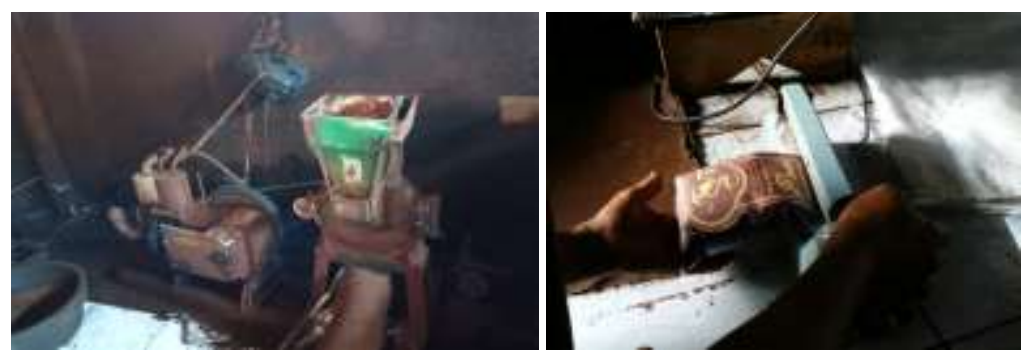

Gambar 2. Kondisi Mesin Penggiling dan Sealer Waktu Survei Lanjutan

Adapun kegiatan koordinasi tim dengan UMKM mitra dapat dilihat pada Gambar 3 di bawah.

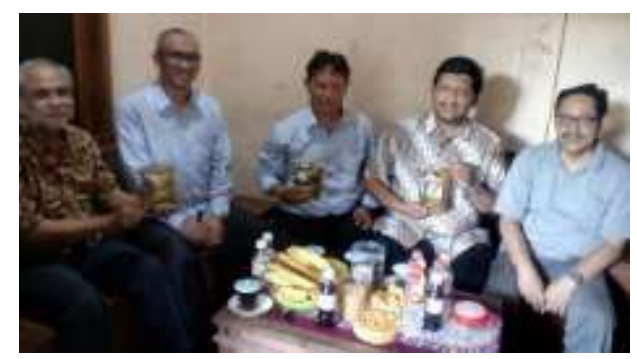

Gambar 3. Koordinasi Tim dengan UMKM Mitra

Hasil dari koordinasi pada pelaksanaan tahap awal ini, tim memfasilitasi penyediaan mesin penggiling kopi dan mesin sealer (pengepres kemasan). Mesin penggiling kopi dan sealer kemasan sudah diserah terimakan kepada UKMK Kopi Lelet Cap Cangkir dan Cap Leo, sebagaimana dapat dilihat pada Gambar 4 di bawah ini. 


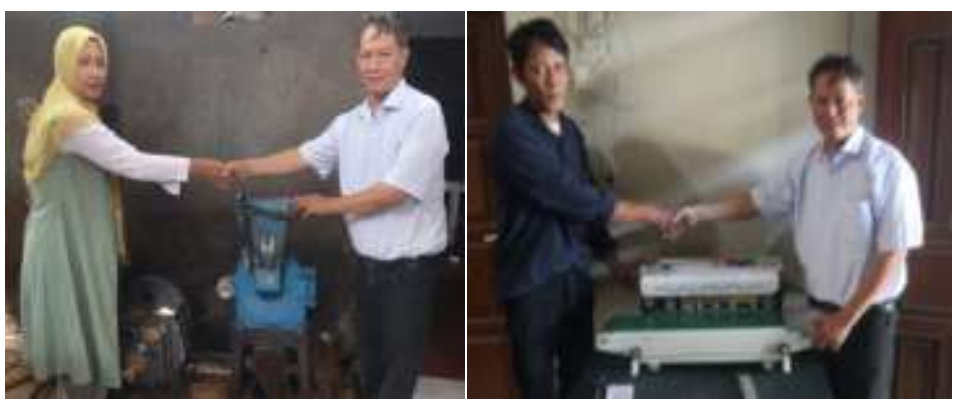

Gambar 4. Serah Terima Mesin

Penyediaan fasilitas mesin penggiling kopi dan mesin sealer dianggap urgen, karena untuk meningkatkan produktivitas produk Kopi Lelet Cap cangkir dan Cap Leo. Produktivitas merupakan penciptaan kekayaan melalui hasil karya penerapan pengetahuan sehingga dapat disediakan produk-produk serta jasa-jasa yang memenuhi kebutuhan para pemakai dan bersifat konsisten dengan tujuan sosial, lingkungan dan ekonomi masyarakat (Monga dalam Mandala dan Raharja, 2012). Produktivitas menurut Kusmindari dan Apriyanto (2009) berkaitan dengan efisiensi dan efektivitas. Efisiensi merupakan suatu ukuran yang menjelaskan tingkat penghematan dalam penggunaan sumber daya, dalam hal ini efisiensi lebih berorientasi pada masukan daripada keluaran. Efektivitas adalah suatu ukuran yang menjelaskan seberapa jauh target dapat dicapai, dalam hal ini efektivitas lebih berorientasi pada keluaran daripada masukan. Sehingga berdasarkan definisi tersebut, dapat dikatakan bahwa peningkatan produktivitas UMKM Kopi Lelet dengan menggunakan mesin penggiling kopi dan sealer diharapkan sangat tepat karena dalam berproduksi UMKM Kopi Lelet Cap Cangkir dan Cap Leo bisa lebih efisien dan efektif guna mencapai tujuan sosial, lingkungan dan ekonomi UMKM.

Untuk menarik para konsumen agar produk UMKM Kopi Lelet Cap Cangkir dan Cap Leo tertarik untuk membeli. Tim juga memberikan masukan agar kemasan produk yang selama ini digunakan oleh UMKM Kopi Lelet Cap Cangkir dan Cap Leo untuk ditambah lagi desain dan model kemasannya dengan harga yang lebih tinggi, serta ada tambahan variasi jenis kopi yang dijual. Menurut Kotler dan Amstrong (2018) peningkatan penjualan suatu produk dipengaruhi oleh faktor internal, yaitu dari sisi pemasaran perusahaan, seperti: promosi, harga, produk dan desain produk, serta faktor eksternal dari konsumen berkaitan dengan perilaku konsumen dalam membeli suatu produk. Artinya, pemasaran produk yang baik juga harus memperhatikan desain dari kemasannya, sehingga bisa menarik konsumen untuk membeli.

Desain produk menurut Kotler dan Keller (2016) adalah pemberian penampilan atau sesuatu yang berbeda pada produk. Desain produk yang berbeda dari yang lain dapat menarik konsumen untuk membeli. Untuk itu, agar penjualan produk Kopi Lelet Cap Cangkir dan Cap Leo bisa meningkat perlu dibuat desain kemasan yang menarik. Selain itu juga perlu ada variasi jenis kopi yang dijual. Gambar 5 dan Gambar 6 di bawah ini adalah desain kemasan dan jenis produk sebelum mendapatkan pendampingan dari tim PKM UNDIP dan sesudah mendapatkan pendampingan. 


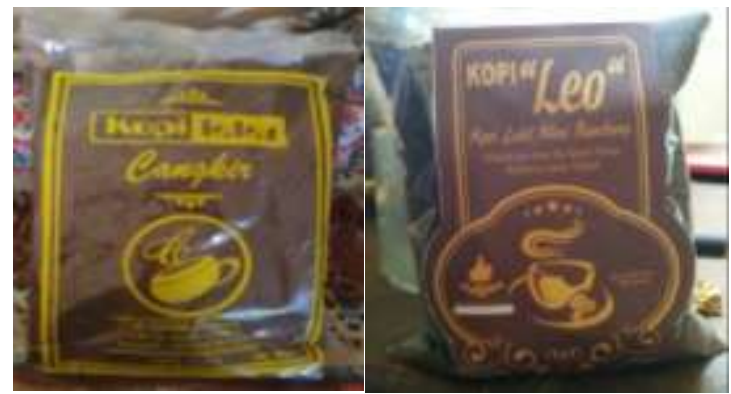

Gambar 5. Desain Kemasan Sebelum Pendampingan
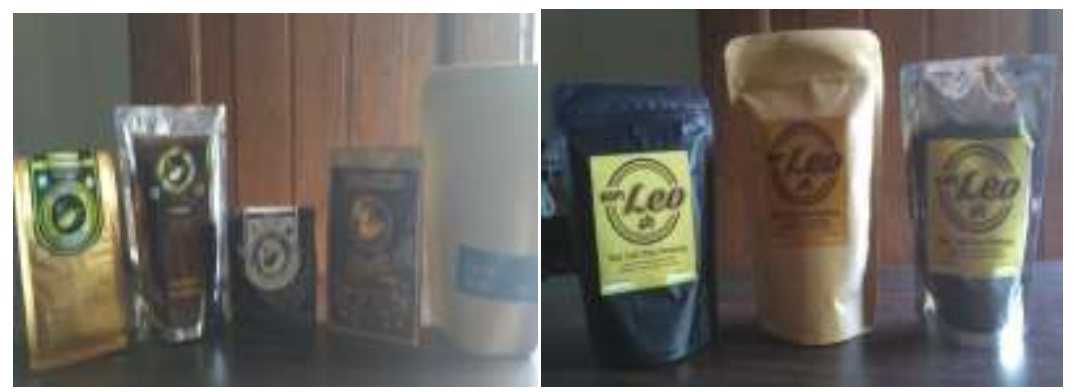

Gambar 6. Desain Kemasan Setelah Pendampingan

Untuk meningkatkan kemampuan berwirausaha dan manajerial UMKM Kopi Lelet Cap Cangkir dan Cap Leo, maka tim melakukan kegiatan pelatihan kewirausahaan dan manajemen, dengan materi tentang kewirausahaan, manajemen keuangan dan manajemen pemasaran. Pelatihan kewirausahaan dan manajemen dilaksanakan adalah untuk meningkatkan pengetahuan dan kemampuan UMKM mitra dalam mengelola usaha sehingga bisa lebih berkembang dan maju. Salah satu kelemahan UMKM adalah masih belum tertibnya administrasi pencatatan transaksi usaha, atau dengan kata lain biasanya UMKM belum memiliki pencatatan laporan keuangan yang baik, dimana belum dipisahkannya kepemilikan dan pengelolaan perusahaan dengan keluarga.

Secara umum UMKM memiliki beberapa kelemahan antara lain: 1) masih lemah dalam persaingan; 2) keterbatasan mengakses pada lembaga keuangan; 3) keterbatasan dalam menjangkau harga sumberdaya energi; 4) keterbatasan teknologi; 5) biaya produksi yang kurang efisien; 6) adanya pengaruh faktor ekonomi, seperti kebijakan pemerintah tentang fiskal dan moneter; 7) kemampuan manajerial yang terbatas; 8) proses produksi yang kurang baik; 9) keterbatasan dalam menjual atau memasarkan produk; dan 10) bahan baku yang sulit dijangkau (Irjayanti dan Aziz, 2012). Kegiatan pelatihan kewirausahaan dan manajemen dilakukan tim UNDIP selama 2 hari pada bulan Agustus 2019, beberapa dokumen pelaksanaan pelatihan dapat dilihat pada Gambar 7 di bawah.

Selain itu Hasil dari pelatihan kewirausahaan dan manejemen usaha, terutama pada pencatatan transaksi keuangan usaha, UMKM Kopi Lelet Cap Cangkir dan Cap Leo sudah bisa secara rutin melakukan pencacatan transaksi usaha harian secara tertib meskipun sangat sederhana. Pencacatan yang dilakukan berupa pemasukan, pengeluaran dan saldo secara harian. Adanya tertib administrasi tersebut, maka UMKM mitra bisa lebih mengetahui omzet 
serta laba sesungguhnya dari usahanya. Sehingga UMKM Kopi Lelet Cap Cangkir dan Cap Leo bisa merencanakan untuk pengembangan usahanya dari kondisi keuangan yang dimiliki.

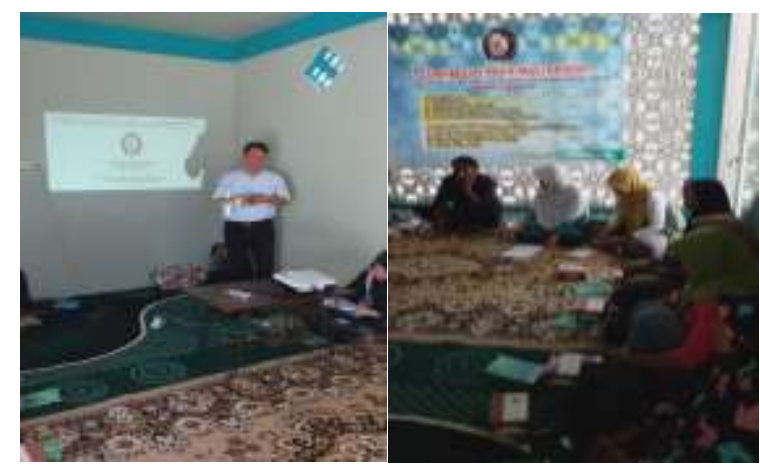

Gambar 7. Kegiatan Pelatihan Kewirausahaan dan Manajemen UMKM

\section{SIMPULAN DAN SARAN}

\section{Simpulan}

Dari hasil kegiatan yang telah dilakukan oleh Tim PKM yang berrmitra dengan UMKM Kopi Lelet Cap Cangkir dan Cap Leo sebagaimana telah dipaparkan sebelumnya di atas, maka dapat diambil kesimpulan sebagai berikut:

1. Tim telah melakukan survei lanjutan dan koordinasi dengan UMKM mitra untuk menggali lebih lanjut tentang permasalahan yang segera harus diberikan solusi. Hasil dari survei lanjutan dan koordinasi tersebut adalah tim untuk segera memfasilitasi penggadaan mesin penggiling kopi dan sealer karena kondisi mesin yang ada sudah tidak layak digunakan. Untuk itu, tim segera memfasilitasi penggadaan mesin penggiling dan sealer. Mesin penggiling kopi dan sealer sudah diserah terimakan oleh tim PKM UNDIP kepada UMKM Kopi Lelet Cap Cangkir dan Cap Leo.

2. Hasil lain dari koordinasi tim dengan UMKM mitra adalah UMKM mitra telah membuat kemasan dengan desain yang lebih menarik dan variatif dengan jenis kopi yang berbeda sesuai dengan masukan dari tim PKM UNDIP.

3. Untuk peningkatan pengetahuan berwirausaha dan kemampuan manajerial, tim telah melakukan pelatihan kewirausahaan dan manajemen usaha UMKM dengan materi tenttang kewirausahaan, manajemen pemasaran dan manajemen keuangan.

4. Hasil dari pelatihan kewirausahaan dan manajemen usaha tersebut, khususnya terkait manajemen keuangan, UMKM mitra yaitu Kopi Lelet Cap Cangkir dan Cap Leo sudah mulai untuk tertib administrasi. UMKM Kopi Lelet Cp Cangkir dan Cap Leo sudah mulai untuk mencatat transaksi keuangan usaha secara harian.

\section{Saran}

Untuk pengembangan usaha UMKM Kopi Lelet Cap Cangkir dan Cap Leo ke depan, maka tim PKM UNDIP menyarankan:

1. UMKM mitra untuk mengajukan sertifikasi produk halal ke Majelis Ulama Indonesia (MUI) dan HAKI merek ke Kemenkumham. 
2. UMKM Kopi Lelet Cap Cangkir dan Cap Leo untuk melakukan diversifikasi produk, seperti membuat kemasan sachetan produk Kopi Lelet Mix dan membuka Coffee Café dengan tujuan agar UMKM mitra semakin berkembang dan pendapatan pendapatan dari UMKM mitra meningkat.

\section{DAFTAR PUSTAKA}

Disperindagkop dan UMKM Kabupaten Rembang (2013). Data UMKM Industri di Kabupaten Rembang.

Dewi, N.L.M.I.M., Budiasa, I.W. \& Dwi, I.A.L. (2015). Analisis Finansial dan Nilai Tambah Pengolahan Kopi Arabika di Koperasi Tani Manik Sedana Kabupaten Bangli. E-journal Agribisnis dan Argowisata. Vol. 54, No. 2. hal. 97 - 106.

Ekawati, Z. (2016). Manfaat Dibalik Secangkir Kopi. Tribun Jogja, 10 Januari 2016, hlm. 13.

Gardjito, M. \& Rahadian A., D. (2011). Kopi. Yogyakarta: Kanisius.

Halik, A., Kasiyati, S.B., Budiarti, E. \& Ratnaningsih (2015). IbM Penggembangan Usaha Warung Kopi Di Deesa Bungah dan Desa Lasem, Kabupaten Gresik. Jurnal Pengabdian LPPM Untag Surabaya. Vol. 01, No. 2, hal. 97 - 104.

http://industri.bisnis.com/read/20160114/99/509504/aeki-konsumsi-kopi-di-pasar-domestiknaik-pesat, diakses tanggal 30 Januari 2017.

Irjayanti, M. \& Azis, A.M. (2012). Barrier Factors and Potential Solutions for Indonesian SMEs. Procedia Economics and Finance. Vol. 4, pp. 3-12.

Kotler, P.T. \& Armstrong, G. (2018). Principles of Marketing. Global Edition, $17^{\text {th }}$ Edition. Pearson.

Kotler, P.T. \& Keller, K.L. (2016). Marketing Management. Global Edition. 15 ${ }^{\text {th }}$ Edition. Pearson. Lembaga Penelitian dan Pengabdian Kepada Masyarakat Universitas Diponegoro (2018). Buku Panduan Penelitian dan Pengabdian Kepada Masyarakat. Edisi V.

Kusmindari, D. \& Apriyanto, A. (2009). Produktivitas dan Pengukuran Kerja Proses Produksi Medium Dencity Fibreboard (MDF). Jurnal Ilmiah TEKNO, Vol. 6 No. 2, hal. 85-96.

Mandala, A. \& Raharja, E. (2012). Peran Pendidikan, Pengalaman, dan Inovasi Terhadap Produktivitas Usaha Kecil Menengah. Diponegoro Journal of Management, Vol. 1. No 1, hal $1-11$.

Panggabean, E. (2011). Buku Pintar Kopi. Jakarta Selatan: PT Agro Media Pustaka. 